\title{
A Visual Sighting and Acoustic Detections of Minke Whales, Balaenoptera acutorostrata (Cetacea: Balaenopteridae), in Nearshore Hawaiian Waters ${ }^{1}$
}

\author{
Shannon Rankin, ${ }^{2}$ Tom F. Norris, ${ }^{3}$ Mari A. Smultea, ${ }^{3}$ Cornelia Oedekoven, ${ }^{3}$ Ann M. Zoidis, ${ }^{3}$ \\ Ethan Silva, ${ }^{4}$ and Julie Rivers ${ }^{5}$
}

\begin{abstract}
Minke whales, Balaenoptera acutorostrata (Lacépède), have been considered a rare species in Hawaiian waters due to limited sightings during visual and aerial surveys. However, our research suggests that they are more common than previously considered. In spring 2005, a combined visual-acoustic survey of cetaceans in Hawaiian waters resulted in the sighting of a minke whale within 22 $\mathrm{km}$ of Kaua'i. Minke whale vocalizations were also detected at several other locations near Kaua' $i$ and $\mathrm{O}^{\prime}$ ahu. These 2005 reports are the first from nearshore $(<50 \mathrm{~km})$ Hawaiian waters despite years of previous shipboard and aerial surveys. The lack of historical sightings is likely due to misidentification or the inability to detect these animals during poor sighting conditions. We recommend that future cetacean surveys in Hawaiian waters include a passive acoustic component to increase the likelihood of detecting minke whales.
\end{abstract}

Minke whales, Balaenoptera acutorostrata (Lacépède), are the smallest baleen whale and are typically solitary animals, occasionally occurring in small groups of two or three (Horwood 1990). There are few low-latitude sightings of minke whales in the North $\mathrm{Pa}$ cific Ocean, and the species is considered rare in Hawaiian waters (Shallenberger 1981). Shallenberger (1981) reported that minke whales occurred seasonally within the Northwestern Hawaiian Islands; however, aerial surveys extending $46 \mathrm{~km}$ (25 nmi) from the main island chain conducted during the years 1993-1998 (Mobley et al. 2000) and 2003 (Mobley 2004) failed to detect any minke

${ }^{1}$ Manuscript accepted 28 September 2006.

2 Southwest Fisheries Science Center, 8604 La Jolla Shores Drive, La Jolla, California 92037 (e-mail: Shannon.Rankin@noaa.gov).

${ }^{3}$ Cetos Research Organization, P.O. Box 885, Bar Harbor, Maine 04609. 94606.

${ }^{4}$ Pelagikos, 499 Embarcadero, Oakland, California

${ }^{5}$ Naval Facilities Engineering Command, Pacific, 258 Makalapa Drive, Suite 100, Pearl Harbor, Hawai'i 96860.

Pacific Science (2007), vol. 61, no. 3:395-398

(C) 2007 by University of Hawai'i Press

All rights reserved whales. Shipboard sightings offshore of the Hawaiian Islands include a juvenile minke whale riding the bow wave of a Navy ship south of Honolulu (Balcomb 1987) and four confirmed and one possible sighting by Hawaiian longline fishery observers (Carretta et al. 2005).

A pilot study consisting of a combined visual-acoustic cetacean survey in the deep waters surrounding the Hawaiian Islands was conducted from 17 to 24 February 2005 aboard the R/V Dariabar (Norris et al. 2005). The Dariabar is a 26.5-m (87-ft) schooner outfitted for visual and passive acoustic detection of cetaceans. The survey track (Figure 1) included waters offshore of O'ahu and Kaua'i, with focused effort in Kaulakahi Channel between Kaua'i and Ni'ihau. In this paper, we present the visual and acoustic records of minke whales detected during this survey.

\section{MATERIALS AND METHODS}

Visual effort consisted of two experienced visual observers rotating between two elevated observation platforms (3.8 $\mathrm{m}$ above sea level) and a crow's nest platform located $7.4 \mathrm{~m}$ above sea level on the mast. Observers scanned the water for cetaceans using $7 \times 50$ 


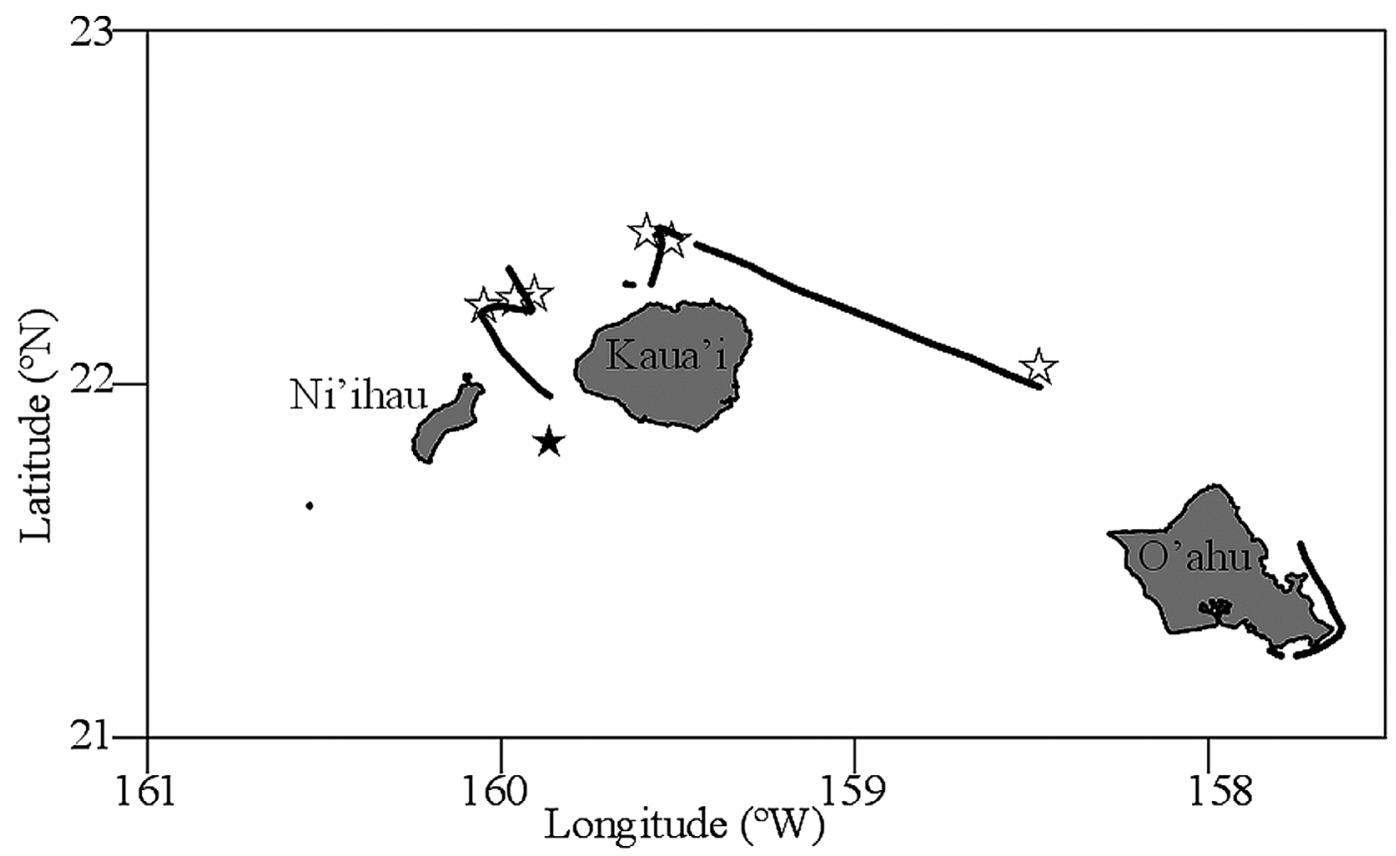

FIGURE 1. Map of the surveyed tracklines, with minke whale sighting (black star) and the six localized acoustic detections of minke whale boing sound sources (white stars) made during the spring 2005 R/V Dariabar cruise.

reticulated binoculars (Fujinon) and unaided eye. Sighting data were recorded to a computer with a real-time Global Positioning System input.

Passive acoustic detection and localization of cetacean vocalizations were accomplished using a two-element hydrophone array (frequency response $500 \mathrm{~Hz}-40 \mathrm{kHz} \pm 10 \mathrm{~dB}$ ) towed $300 \mathrm{~m}$ behind the vessel. The signal conditioning and acquisition system consisted of a mixing board (Behringer Europro) for signal conditioning (amplification, equalization, and filtering) and a PCMIA data acquisition card (National Instruments model $6062 \mathrm{E})$. Bearing angles to sound sources were determined using Ishmael signal analysis software (Mellinger 2001), which computes the time delay between hydrophones via a crosscorrelation algorithm to determine bearing angles to the sound source. Bearing angles were plotted using Whaltrak, a plotting and data-logging program developed by Southwest Fisheries Science Center. Localization of sound sources was determined by the convergence of sequential bearings over time.

\section{RESULTS AND DISCUSSION}

At 1315 hours on 21 February 2005, a minke whale was sighted $20.7 \mathrm{~km}$ (11.1 nmi) southwest of Kaua'i (Figure 1). The whale surfaced approximately $100 \mathrm{~m}$ off the port stern of the Dariabar $\left(21^{\circ} 50.18^{\prime} \mathrm{N}, 159^{\circ} 51.91^{\prime} \mathrm{W}\right)$ within a group of 15 pilot whales and near a group of three humpback whales. Species identity was confirmed by several experienced marine mammal observers during multiple surfacings. Diagnostic characteristics included the animal's small body size, falcate dorsal fin, and triangular rostrum. Soon after the sighting, a small inflatable boat was launched from the Dariabar; resighting and behavior information was relayed between an observer on the crow's nest and the scientist in the small boat until 1615 hours. Our results provide the first confirmed visual detection of a minke 
whale in nearshore waters of the main $\mathrm{Ha}$ waiian Islands.

"Boing" sounds recently attributed to minke whales (Rankin and Barlow 2005) were detected at the same time, and in the vicinity of, the visual sighting of the minke whale and at other locations during the survey. Technical difficulties and the presence of multiple species in the area prevented us from conclusively linking these particular boing sounds to the sighted minke, although bearing angles to boing vocalizations were consistent with the angles to the minke whale determined by the visual observers. The intensity of these sounds also decreased as the animal increased its distance from the Dariabar, suggesting that the sounds may have been produced by the sighted minke whale.

Passive acoustic localization of cetacean vocalizations was performed during $283 \mathrm{~km}$ $(152.8 \mathrm{nmi})$ of trackline in the deep offshore waters of Kaua' $\mathrm{i}$ and $\mathrm{Ni}^{\text {'ihau }}$ from 22 to 24 February 2005. Localization of boing vocalizations resulted in a minimum of six vocalizing whales (Figure 1). Not all boing sounds could be localized; therefore, this represents a minimum estimate of vocalizing minke whales in the study area. The number of minke whale boings detected during this survey was second only to the detection of the ubiquitous humpback whale song.

Population studies of cetaceans typically rely on visual detection of animals from shipboard and aerial platforms. Minke whales are notoriously difficult to detect using visual methods due to their small size, short surfacing intervals, and lack of a visible blow (Joyce et al. 1990, Gunnlaugsson 1991, Rankin and Barlow 2005). The high sea states caused by the trade winds in the Hawaiian Islands further inhibit the visual detection of minke whales. The discrepancy between the suggested distribution of minke whales in Hawaiian waters determined by acoustic versus visual methods is likely due, at least in part, to the predominant local weather conditions. The minke whale sighting described in this paper occurred during ideal sighting conditions (Beaufort sea state $0-1$ ). Our research suggests that minke whales may be more common in Hawaiian waters than previously believed, and that due to difficulties in visual detection of minke whales passive acoustics may be critical in understanding the population structure of minke whales in these waters.

\section{ACKNOWLEDGMENTS}

We thank Bonnie Patton, Charlie Patton, and Craig Hawkinson of the R/V Dariabar for their expert shiphandling skills and assistance in the field. Julie Hayes, Christine Loftus, and Liz Zele assisted in postcruise analysis of data. Funding and logistical support was provided by Cetos Research Organization, Pelagikos, and the U.S. Navy.

\section{Literature Cited}

Balcomb, K. M. 1987. The whales of Hawai $i$, including all species of marine mammals in Hawaiian and adjacent waters. Publ. Marine Mammal Fund, San Francisco, California.

Carretta, J. V., K. A. Forney, M. M. Muto, J. Barlow, J. Baker, B. Hanson, and M. S. Lowry. 2005. U.S. Pacific marine mammal stock assessments: 2004. NOAA Tech. Mem. NOAA-TM-NMFS-SWFSC-375. Available from SWFSC, 8604 La Jolla Shores Drive, La Jolla, California 92037.

Gunnlaugsson, T. 1991. Effect of Beaufort on minke whale sightings rate in Icelandic whale observation surveys 1982-1986. (IWC SC/42/NHMi-25). Rep. Int. Whaling Comm. 41:445-448.

Horwood, J. 1990. Biology and exploitation of the minke whale. CRC Press, Boca Raton, Florida.

Joyce, G. G., J. Sigurjonsson, and G. Vikingsson. 1990. Radio tracking a minke whale (Balaenoptera acutorostrata) in Icelandic waters for the examination of dive-time patterns (SC/41/NHMi13). Rep. Int. Whaling Comm. 40:357-361.

Mellinger, D. K. 2001. Ishmael 1.0 user's guide. NOAA Tech. Mem. OAR PMEL120. Available from NOAA/PMEL, 7600 Sand Point Way, NE, Seattle, Washington 98115-6349.

Mobley, J. R., Jr. 2004. Results of marine 
mammal surveys on U.S. Navy underwater ranges in Hawaii and Bahamas. Final Report to Office of Naval Research. Available at http://socrates.uhwo.hawaii.edu/ SocialSci/jmobley/ONRfinal.pdf.

Mobley, J. R., Jr., S. S. Spitz, K. A. Forney, R. A. Grotefendt, and P. H. Forestell. 2000. Distribution and abundance of odontocete species in Hawaiian waters: Preliminary results from 1993-98 aerial surveys. Admin. Rep. LJ-00-14C. Available from SWFSC, 8604 La Jolla Shores Drive, La Jolla, California 92037.

Norris, T. F., M. A. Smultea, A. M. Zoidis, S. Rankin, C. Loftus, C. Oedekoven, J. L. Hayes, and E. Silva. 2005. A preliminary acoustic-visual survey of cetaceans in deep waters around $\mathrm{Ni}^{\prime}$ ihau, Kaua'i, and portions of $\mathrm{O}^{\prime}$ ahu, Hawai' $\mathrm{i}$ from aboard the R/V Dariabar, February 2005. Prepared by Cetos Research Organization, Bar Harbor, Maine, under contract no. 2057sa05-F to Geo-Marine, Inc. for NAVFAC Pacific. (Excerpts available from http:// www.cetosresearch.org.)

Rankin, S., and J. Barlow. 2005. Source of the North Pacific "boing" associated with minke whales. J. Acoust. Soc. Am. 188 (5): 3346-3351.

Shallenberger, E. W. 1981. The status of Hawaiian cetaceans. Marine Mammal Commission Report No. MMC-77/23. 